\title{
Dams on the Mekong River: Lost fish protein and the implications for land and water resources
}

\author{
Stuart Orr ${ }^{\mathrm{a}, *}$, Jamie Pittock $^{\mathrm{b}}$, Ashok Chapagain ${ }^{\mathrm{c}}$, David Dumaresq ${ }^{\mathrm{d}}$ \\ ${ }^{a}$ WWF International, Ave du Mont Blanc, Gland 1196, Switzerland \\ ${ }^{\mathrm{b}}$ Crawford School of Economics \& Government, Australian National University, Canberra ACT 0200, Australia \\ ${ }^{\mathrm{c}}$ WWF UK, Panda House, Weyside Park, Godalming, Surrey GU7 1XR, United Kingdom \\ ${ }^{\mathrm{d}}$ Fenner School of Environment \& Society, Australian National University, Canberra ACT 0200, Australia
}

\section{A R T I C L E I N F O}

\section{Article history:}

Received 18 March 2011

Received in revised form 24 May 2012

Accepted 9 June 2012

Available online 15 July 2012

\section{Keywords:}

Dam

Environmental impact assessment

Fish

Freshwater

Food security

Hydropower

Land footprint

Protein

Water footprint

\begin{abstract}
A B S T R A C T
Proposed dam construction in the Lower Mekong Basin will considerably reduce fish catch and place heightened demands on the resources necessary to replace lost protein and calories. Additional land and water required to replace lost fish protein with livestock products are modelled using land and water footprint methods. Two main scenarios cover projections of these increased demands and enable the specific impact from the main stem dam proposals to be considered in the context of basin-wide hydropower development. Scenario 1 models 11 main stem dams and estimates a 4-7\% increase overall in water use for food production, with much higher estimations for countries entirely within the Basin: Cambodia (29-64\%) and Laos (12-24\%). Land increases run to a 13-27\% increase. In scenario 2, covering another 77 dams planned in the Basin by 2030 and reservoir fisheries, projections are much higher: 6$17 \%$ for water, and $19-63 \%$ for land. These are first estimates of impacts of dam development on fisheries and will be strongly mediated by cultural and economic factors. The results suggest that basic food security is potentially at a high risk of disruption and therefore basin stakeholders should be fully engaged in strategies to offset these impacts.
\end{abstract}

(c) 2012 Elsevier Ltd. All rights reserved.

\section{Introduction}

There are contested plans for 11 hydropower dams on the freeflowing main stem of the lower Mekong River in south-east Asia and 77 other dams in the Mekong Basin as a whole (ICEM, 2010b; Molle et al., 2009). The Mekong River (known as the Lancang River in China) rises from the Tibetan Plateau and flows for approximately 4800 km through China, Myanmar, Laos, Thailand, Cambodia and Viet Nam, where it forms a large delta in the South China Sea. The river drains a total catchment area of $795,000 \mathrm{~km}^{2}$ and receives $18 \%$ of its inflows from the $24 \%$ of the Basin located in China and Myanmar (Campbell, 2009; MRC, 2005). The Lower Mekong Basin (LMB) countries collaborate in the management of their portion of the Basin through the Mekong River Commission (MRC) (Osborne, 2009).

The total estimated hydropower potential in the Mekong Basin is 53,000 megawatts (MW) (ICEM, 2010b). To date, 17 hydro

\footnotetext{
* Corresponding author. Tel.: +4122 3649014.

E-mail addresses: sorr@wwfint.org (S. Orr), jamie.pittock@anu.edu.au (J. Pittock), achapagain@wwf.org.uk (A. Chapagain), david.dumaresq@anu.edu.au (D. Dumaresq).
}

schemes on tributary rivers have been completed, totalling more than $1600 \mathrm{MW}$, or $5 \%$ of the potential (MRC, 2005). The LMB mainstream dams represent up to $14,697 \mathrm{MW}$, or $23-28 \%$ of the national hydropower potential of the four LMB countries (ICEM, 2010b). This indicates that many options exist in the Mekong Basin for hydropower development off the main stem, although a number of future sites may be unsuitable for social and environmental reasons. The economic value of hydroelectric power currently generated from the Mekong is estimated at USD \$235 million per year (MRC, 2005), while the environmental impacts have been less rigorously quantified.

Today 60 million people (12 million households) live in the LMB, and $80 \%$ rely directly on the river system for their food and livelihoods (Baran and Myschowoda, 2009; ICEM, 2010b). Most of these households would be affected by alterations to fish availability, as fish is the main source of dietary protein (MRC, 2005). Relatively unexplored impacts on the LMB nations (Cambodia, Laos, Thailand and Viet Nam) must be addressed in detail in order to clarify what strains on food security would result from the proposed projects.

Policy makers have often failed to recognize the crucial role of inland fisheries in meeting food security (Smith et al., 2005; Béné and Friend, 2011), often in the face of strong scientific evidence 
(Friend, 2009). Debate centring on resource constraints and trade-offs is moving toward how policies can be informed by a clearer understanding of the price paid for progress (Bonn, 2011; WEF, 2011). Within this debate is an inherent need for better resource planning and wider recognition of the implications of poor decision-making concerning shared resources. Shifting the food security of 12 million households from heavy reliance on aquatic protein to a more rainfed, land-based economy has obvious and significant challenges. The resulting political, economic, social and institutional gaps are wide enough to merit further analysis and exploration. The on-going debate over the Xayaburi dam in Laos is a case in point. The USD \$3.8 billion dam is the first of 11 planned for the lower main stem: yet continued uncertainties about the downstream impacts to the ecology and livelihoods, as well as food supply have led to the project's being stalled (BBC, 2011). If the proposed dams are built, it is not only the impacts on the food supply, but also the strategies, investment and handling of numerous natural resources and social issues which must be considered.

Dam construction has almost always created conflicts between energy supply and related economic interests, versus their social and environmental impacts (King et al., 2007; WCD, 2000). One recent review focussing on the decade since the end of the World Commission of Dams (WCD) Report highlights undiminished controversy surrounding impacts (Moore et al., 2010). For example, Richter et al. (2010) give new estimates on the number of downstream river-dependent populations affected by existing dams (472 million globally). Yet while a number of stakeholder processes have resulted in principles, recommendations, tools and protocols to minimize the impacts of hydropower dams while maximizing their benefits (IHA, 2006; King et al., 2007; WCD, 2000), few new projects have applied these principles (WWF, 2005).

The strategic environmental assessment (SEA) of hydropower on the Mekong main stem concluded that the main stem projects would have significantly negative net impacts on both fisheries and agricultural sectors (ICEM, 2010b). The losses in fisheries due to the main stem dams were estimated at USD \$476 million per year, excluding effects on the coastal and delta fisheries. In addition, there would be extensive impacts on riverbank gardens along the Mekong which would result in losses calculated as USD \$20.7 million/year (ICEM, 2010a),

In each country, $47-80 \%$ of animal protein for local residents comes from freshwater fisheries, and $90 \%$ of this is from capture fisheries (Hortle, 2007). The magnitude of the freshwater fisheries catch in the LMB is contested and estimates vary. We rely on the most recent SEA estimate of capture fish production of more than 2 million tonnes of fish per year with a first sale value of USD \$1.4 to 2 billion per year: a retail value of up to USD $\$ 4.2$ to 7.6 billion per year (ICEM, 2010a,b). The per capita freshwater fish consumption of the LMB has been estimated at $33.7 \mathrm{~kg} /$ person/yr (Hortle, 2007) or around $80 \mathrm{~g}$ per person per day for each of the 60 million people in the Basin (Baran and Myschowoda, 2009).

Wet season flood pulses in the Basin drive major fish recruitment, inundating a large floodplain that backs up into the Tonle Sap Lake in Cambodia. Dams would attenuate these flood pulses and reduce fish recruitment. The Mekong Basin is particularly rich in biodiversity, with 850 freshwater fish species, or as many as 1100 if coastal or marine visitors are included. At least $35 \%$ of the fish yield in the Mekong is comprised of species that require migrations of up to a thousand kilometres or more for reproduction (Barlow et al., 2008; ICEM, 2010a,b). Recruitment of these fish species would be "fundamentally" undermined as dams form barriers to migration (ICEM, 2010b).

The construction of fish passages on the proposed dams or other such technologies cannot significantly mitigate the effects of the dams (Dugan, 2008; ICEM, 2010b). The height of 5 of the 11 proposed mainstream dams is more than $50 \mathrm{~m}$ (ICEM, 2009), making the installation of effective fish passes virtually impossible. All barriers to fish passage take a cumulative toll on migrating fish. For instance, $5-14 \%$ of adult salmon are killed at each of the eight dams they pass while swimming up the Columbia River in the USA (Eley and Watkins, 1991). To be effective, fish passages must be properly operated to ensure adequate flows at these constrictions. The WCD reports that for 87 dam projects globally, mitigation was undertaken for less than one-quarter of them. In 47 of these projects where there was data, $40 \%$ of mitigation measures did not work, $40 \%$ were moderately effective and only $20 \%$ worked effectively (WCD, 2000). In the lower Mekong for instance, to sustain fish migration, effective operations would be required on all of the 11 proposed dams.

Fish species have different capabilities and habits (WCD, 2000). Even if fish ladders were installed, they would be unlikely to facilitate passage of the large number of migratory species that have different behavioural characteristics. The failure of the fish ladder of the Pak Mun Dam in the Mekong Basin illustrates the problem. As one report states, "The fish catch directly upstream of the dam has declined by $60-80 \%$ after the completion of the project [but this] may well be exacerbated by the cumulative impact of many different developments in the watershed" (Amornsakchai et al., 2000:8). In the post-dam period, fishing communities located upstream and downstream of the dam reported a $50-100 \%$ decline in fish catch and the disappearance of many fish species.

The MRC Secretariat's international Expert Group advised that "there is currently no evidence that fish-passage facilities used in large tropical rivers in Latin America, Africa and Asia can cope with the massive fish migrations and high species biodiversity in the Mekong. [...] current fish-passage technology would not be effective in maintaining the migration of the large number and diverse fish species found in the Mekong" (Dugan, 2008:12). The SEA concludes that "Fish passes are not a realistic mitigation option for Mekong mainstem dams" (ICEM, 2010b:16), meaning that the transference of technologies must be adapted to sitespecific circumstances.

\section{Objective}

Our research examines the 11 planned dam projects on the main stem of the Mekong River in Laos, Thailand and Cambodia as detailed by ICEM (2009), and another 77 dams planned in the Basin by 2030. The LMB countries have been chosen for the more consistent data available due to their common institution, the Mekong River Commission (MRC). Additionally, these states are likely to experience the greatest impacts from the proposed dams (Osborne, 2009).

Likely human food supply interruptions must be assessed in terms of lost protein and overall calories. Using the fish loss estimations from the SEA, we estimate the additional land and water needs that would be required to replace lost fish protein. Some estimations of this shift have been made before (Baran and Myschowoda, 2009; ICEM, 2010b), but have been relatively anecdotal. Here we employ land and water footprint methods to attain more specific and realistic assessments.

The history of documented local reductions in fish catches on the Pak Mun, Sesan and Nam Theun and Hinboun river tributaries of the Mekong vary from $30 \%$ to $90 \%$ - generally falling at the more severe end of this range following the completion of dams (ADB, 2001; Baird and Mean, 2005; The Theun-Hinboun Power Company Limited, 2000). In this context, the estimates of loss of fish production in the Mekong Basin in 2030 compared to a 2000 baseline, due to dam development by the SEA (Table 1) appears conservative. The assessment concludes that basin-wide 
Table 1

Volume and portion of changes in fish resources in the Mekong Basin. ICEM (2010a).

\begin{tabular}{|c|c|c|}
\hline Changes in fish catch forecast for 2030 & $\begin{array}{l}\text { Change in wild freshwater } \\
\text { fish catch (tonnes) }\end{array}$ & $\begin{array}{l}\text { Change in fish } \\
\text { resources (\%) }\end{array}$ \\
\hline $\begin{array}{l}\text { Scenario } 1 \text { ( } \mathrm{S} 1-11) \text { : Losses due to the } 11 \text { main } \\
\text { stem dams planned for the Mekong }\end{array}$ & $-340,000$ & -16 \\
\hline $\begin{array}{l}\text { Losses due to the net impact of } 77 \text { proposed } \\
\text { tributary dam development by } 2030\end{array}$ & $-210,000$ to $-540,000$ & -10 to -26 \\
\hline Sum of losses in capture fisheries from 88 dams & $-550,000$ to $-880,000$ & -26 to -42 \\
\hline $\begin{array}{l}\text { Minus the highest estimate of gains ( } 10 \% \text { of capture } \\
\text { fishery losses) in fish production from reservoir fisheries }\end{array}$ & $+55,000$ to $+88,000$ & +2.6 to +4.2 \\
\hline $\begin{array}{l}\text { Scenario } 2 \text { (S2-88): Resulting net losses in fish resources } \\
\text { from all } 88 \text { dams planned for the Mekong }\end{array}$ & $-495,000$ to $-792,000$ & -23.4 to -37.8 \\
\hline
\end{tabular}

development of 77 dams is expected to reduce fish production by $210,000-540,000$ tonnes or $10-26 \%$. It further states that if the 11 main stem dams were also built, the total loss in fish resources would be $550,000-880,000$ tonnes or $26-42 \%$ (ICEM, 2010b). Thus the losses directly attributable to the 11 main stem dams would be 340,000 tonnes: a $16 \%$ reduction (Table 1 ). The MRC Secretariat's international Expert Group assessed the option of replacing fish loss with aquaculture and concluded that, "On the basis of this evidence, compensation for loss in yield from river fisheries is impossible to achieve through development of reservoir fisheries" (Dugan, 2008). The SEA estimates that new reservoir fisheries would replace only $10 \%$ of the capture fisheries losses as the impoundments are not able to support the same fish species diversity as the natural riverine system, especially where dams in cascades create barriers to upstream migration of reservoir species towards tributaries (ICEM, 2010b).

\section{Methods}

The key questions explored in this research are assessed through two scenarios. These scenarios were chosen due to the availability of data that was accepted by LMB authorities from the Strategic Environmental Assessment (ICEM, 2010b).

1. Scenario 1 (S1-11): Replacement of 340,000 tonnes (16\% reduction) of lost fish protein directly attributable to the proposed 11 main stem dams; and

2. Scenario 2 (S2-88): Replacement of the net loss in fish protein due to the impact of all 88 proposed dam developments by 2030 .

The two scenarios enable the specific impact from the main stem dam proposals to be considered in the context of basin-wide hydropower development. As hydro-power development on tributaries in the basin is already underway, the second scenario incorporates the more likely development of tributary dams and one to which we have applied the off-setting contribution of reservoir fisheries identified by ICEM (2010b). These scenarios are assessed for the Mekong Basin as a whole and for each LMB nation, which are expressed at minimum and maximum ranges representing their shares of the total identified Mekong capture fishery output. The volume of water and area of land that is needed to substitute alternative food supplies for lost fish catch is quantified. The indirect impacts of the planned LMB dams are calculated on SEA forecast losses in fish catch, and quantified using the concepts of water and land footprints. These approaches can provide decision makers with a picture of trade-offs in measures (water requirements and area of land) that are easily understood and visualised from both a practical and policy perspective. Assessments methods such as cost benefit analysis (CBA) may often obscure the values and complexity of impacts by placing monetary values outside of a more integrated context, thereby distorting the true representation of costs and benefits (Söderbaum, 2009). We recognise that the land and water approaches used do not provide enough information to judge what is right or wrong, but they do enable discussion around the burdens incurred by fish loss as a consideration of trade-offs in a real world political, economic and policy perspective.

In this assessment, the size of the flood pulse and resulting fish recruitment is assumed to be unaltered by the run-of-river dams (even though some additional impacts are likely). The main impact is assumed to be the prevention of migration for the fish that depend on these conditions and a concomitant reduction in recruitment and catch. Furthermore, we have not calculated the land-based protein sources that would be lost with the inundation of $1350 \mathrm{~km}^{2}$ of riverside lands.

To estimate the water required to replace protein supplies, we have used water footprint accounting (Hoekstra et al., 2011). This accounting framework emerged from the virtual water concept (Allan, 1998, 2001) which described the water embedded through crop production in international trade. The concept of virtual water took on more quantitative applications once researchers began to estimate and calculate global virtual water flows (Chapagain and Hoekstra, 2004, 2008; de Fraiture et al., 2004; Mekonnen and Hoekstra, 2011; Oki and Kanae, 2004). This led to the evolution of the concept of water footprint (hereafter WF), the summation of virtual water use within a specific spatial area.

Numerous studies of WF scenarios have looked across products and locations, but none have analysed the impacts of loss in protein and calorific value due to a reduction or loss of fish catch. The virtual water content, the total volume of water used in the production process expressed as $\mathrm{m}^{3}$ per tonnes of product, is taken from Chapagain and Hoekstra (2004). The WF of the substitute diet is calculated as the sum of virtual water content of all the products consumed. This accounts for larger and more realistic quantifications of water volumes involved in production processes, with implications for protein and calorie replacement scenarios.

The substitution of lost calorie and protein would come from alternative sources and could vary in composition depending on availability. Protein could be partially imported from outside the Basin. Currently, many LMB residents have limited means to pay for such imports. Protein-rich crops could be grown locally, including soybeans and nuts: although such a major shift in diet away from meats might not be culturally acceptable (and has not been modelled here.) Third, replacement fish protein could be grown through aquaculture. Modelling the substantial land, water and feedstock implications of this option in future research would be worthwhile. Combinations of possible alternative compositions will evolve over time, but in this paper we model what we consider to be the most likely option - a scaling up of existing non-fish milk and livestock products already grown and consumed in the LMB region. We assume that lost protein will be replaced by animal protein rather than from crops, given dietary preferences in the region, tradition of animal husbandry, and the current exploitation of the highest quality lands for cropping. 
Our assessment is conservative for two reasons. First, it assumes that the demand for food will remain static with time and does not estimate the demand and sources for increasing populations of the LMB countries. Second, the share of protein to total calories in the existing diet composition is modelled as constant which contradicts the global trend where it increases with wealth. The high cost of protein supplies prohibit radical increases, given limited incomes of the fish-dependent population.

The substitute protein and calorie values are allocated to various livestock products based on a proportional increase in their share to total protein values, in the existing diets of each LMB country. The total quantity of additional meat and dairy products are calculated based on the unit of calorie and protein content of each product. The volume of water needed to produce replacement protein is calculated using the virtual water content of production. The WF calculations do not account for the different sources of water use such as ground or surface water (blue water), and for the use of soil moisture maintained by rainfall (green water); nor do they account for the volume of freshwater polluted in the process of shifting to land base agriculture. While this methodology is robust in assessing the amount of water consumed in production processes, the numbers should be treated as approximations, as we have used country averaged climate and production variables to obtain the virtual water content in the region.

\section{Data}

Primary data on how much of the Mekong fish catch is at risk from main stem dam development is contested. We rely on the SEA assessment (ICEM, 2010a) as the most recent and authoritative source of the portion of fish catch at risk from the proposed dams (Table 1).

The data on gross annual production, export, import and consumption of the main, non-fish meat products in Cambodia, Laos, Thailand and Viet Nam is obtained from FAOSTAT (FAO, 2005, 2008). The major livestock items taken for the study are 'beef', 'eggs', 'milk', 'pig meat', 'poultry meat', 'sheep and goat meat'. In the period 2005-2007, the annual production of these products in the LMB countries was $13,376,000$ tonnes/y, the total import was $2,137,000$ tonnes/y with a total export of 783,000 tonnes/y. In the same period, the total consumption of these products as food was $6,040,000$ tonnes/y. To consider the implications for substitute foodstuffs, Table 2 gives a detailed breakdown of individual nonfish protein products by country and the share of each product to the total calorie and protein equivalents for the period 2005-2007.

The conversion factors used to calculate the equivalent calorie and protein values of different animal-based products are taken from FAO (2001) and summarised in Table 3, where fish has an energy equivalent of $69 \mathrm{Kcal} / 100 \mathrm{~g}$ and a protein level of $11 \mathrm{~g} /$ $100 \mathrm{~g}$.

Using the conversion factors (Table 3 ) for fish loss, the equivalent losses in terms of calories and protein are calculated for each country (Table 4). There are varying estimates of the portion of the total fish catch by each nation. Here we take the minimum and maximum estimates of the national portion of the Mekong fish catch as reported by the SEA (ICEM, 2010a) in order to calculate a range of potential losses in fish calorie and protein supply by nation.

The main contribution of fish to food and nutrition security is arguably not through calories or protein content, but through their

Table 2

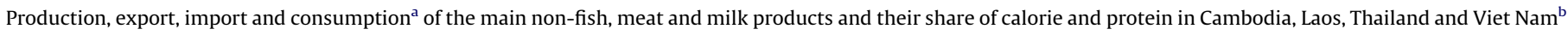
(tonnes/y). Period 2005-2007 (FAO, 2005, 2008).

\begin{tabular}{|c|c|c|c|c|c|c|c|c|c|}
\hline & \multirow[t]{2}{*}{ Products } & \multicolumn{4}{|c|}{ Quantity'000 tonnes/y } & \multicolumn{2}{|c|}{ Equivalent calorie value } & \multirow{2}{*}{$\begin{array}{l}\begin{array}{l}\text { Equivalent } \\
\text { value }\end{array} \\
\text { Protein } \\
\text { tonnes/y }\end{array}$} & \multirow{2}{*}{$\begin{array}{l}\text { protein } \\
\begin{array}{l}\text { Protein } \\
\text { share }\end{array}\end{array}$} \\
\hline & & Production & Import & Export & $\begin{array}{l}\text { Consumed } \\
\text { as food }\end{array}$ & $10^{-6} \mathrm{Kcal} / \mathrm{yr}$ & $\begin{array}{l}\text { Calorie } \\
\text { share }\end{array}$ & & \\
\hline \multirow[t]{7}{*}{ Cambodia } & Beef and buffalo meat & 70 & 0.2 & 0.0 & 70 & 53,643 & $12 \%$ & 7872 & $23 \%$ \\
\hline & Eggs primary & 17 & 0.0 & 0.0 & 16 & 22,240 & $5 \%$ & 1712 & $5 \%$ \\
\hline & Milk & 23 & 59.5 & 0.0 & 81 & 49,613 & $11 \%$ & 2684 & $8 \%$ \\
\hline & Pig meat & 131 & 0.1 & 0.0 & 132 & 290,400 & $63 \%$ & 17,688 & $51 \%$ \\
\hline & Poultry meat & 26 & 0.0 & 0.0 & 26 & 48,100 & $10 \%$ & 4446 & $13 \%$ \\
\hline & Sheep and goat meat & 0 & 0.0 & 0.0 & 0 & 0 & 0 & 0 & 0 \\
\hline & Total & 266 & 59.9 & 0.0 & 325 & 463,997 & $100 \%$ & 34,402 & $100 \%$ \\
\hline \multirow[t]{7}{*}{ Laos } & Beef and buffalo meat & 41 & 0.0 & 0.0 & 41 & 31,827 & $16 \%$ & 4671 & $29 \%$ \\
\hline & Eggs primary & 14 & 0.0 & 0.0 & 11 & 15,753 & $8 \%$ & 1213 & $8 \%$ \\
\hline & Milk & 7 & 27.7 & 0.0 & 27 & 16,673 & $8 \%$ & 902 & $6 \%$ \\
\hline & Pig meat & 43 & 0.0 & 0.0 & 43 & 93,867 & $47 \%$ & 5717 & $35 \%$ \\
\hline & Poultry meat & 20 & 0.0 & 0.0 & 20 & 37,617 & $19 \%$ & 3477 & $22 \%$ \\
\hline & Sheep and goat meat & 1 & 0.0 & 0.0 & 1 & 2630 & $1 \%$ & 135 & $1 \%$ \\
\hline & Total & 125 & 27.7 & 0.0 & 144 & 198,367 & $100 \%$ & 16,115 & $100 \%$ \\
\hline \multirow[t]{7}{*}{ Thailand } & Beef and buffalo meat & 299 & 2.3 & 3.5 & 296 & 228,177 & $4 \%$ & 33,486 & $9 \%$ \\
\hline & Eggs primary & 817 & 0.1 & 11.7 & 621 & 863,190 & $17 \%$ & 66,447 & $17 \%$ \\
\hline & Milk & 846 & 1147.6 & 285.7 & 1598 & 974,983 & $19 \%$ & 52,745 & $14 \%$ \\
\hline & Pig meat & 805 & 0.5 & 10.2 & 793 & $1,743,867$ & $34 \%$ & 106,217 & $28 \%$ \\
\hline & Poultry meat & 1052 & 0.6 & 453.6 & 731 & $1,352,350$ & $26 \%$ & 125,001 & $33 \%$ \\
\hline & Sheep and goat meat & 1 & 0.7 & 0.0 & 2 & 5260 & $0 \%$ & 270 & $0 \%$ \\
\hline & Total & 3820 & 1151.9 & 764.5 & 4041 & $5,167,827$ & $100 \%$ & 384,166 & $100 \%$ \\
\hline \multirow[t]{8}{*}{ Viet Nam } & Beef and buffalo meat & 275 & 1.3 & 0.6 & 275 & 212,007 & $3 \%$ & 31,113 & $6 \%$ \\
\hline & Eggs primary & 207 & 0.0 & 1.4 & 189 & 262,710 & $4 \%$ & 20,223 & $4 \%$ \\
\hline & Milk & 247 & 823.6 & 2.0 & 968 & 590,683 & $8 \%$ & 31,955 & $6 \%$ \\
\hline & Pig meat & 2449 & 5.7 & 14.5 & 2443 & $5,373,867$ & $73 \%$ & 327,317 & $66 \%$ \\
\hline & Poultry meat & 428 & 66.3 & 0.0 & 494 & 913,900 & $12 \%$ & 84,474 & $17 \%$ \\
\hline & Sheep and goat meat & 10 & 0.6 & 0.0 & 11 & 28,930 & $0 \%$ & 1485 & $0 \%$ \\
\hline & Total & 3616 & 897.5 & 18.4 & 4380 & $7,382,097$ & $100 \%$ & 496,567 & $100 \%$ \\
\hline & Lower Mekong nations' total & 7827 & 2137 & 782.9 & 8891 & $13,212,287$ & & 931,250 & \\
\hline
\end{tabular}

a Note that major portions of Thailand and Viet Nam lie outside the Basin.

b The consumption figures here do not fully tally with production plus imports minus exports due to wastage and reporting discrepancies. 
Table 3

Conversion factors for equivalent calorie and protein value of meat and dairy products. FAO (2001).

\begin{tabular}{lcc}
\hline Products & $\begin{array}{l}\text { Energy } \\
\text { Kcal/100g }\end{array}$ & $\begin{array}{l}\text { Protein } \\
\mathrm{g} / 100 \mathrm{~g}\end{array}$ \\
\hline Beef and buffalo meat & 77 & 11.3 \\
Eggs primary & 139 & 10.7 \\
Milk & 61 & 3.3 \\
Pig meat & 220 & 13.4 \\
Poultry meat & 185 & 17.1 \\
Sheep and goat meat & 263 & 13.5 \\
Fish & 69 & 11.0 \\
\hline
\end{tabular}

supply of micronutrients (Vitamin A, iron, calcium, and zinc) and lipids to micronutrient deficient populations. Some comparisons in terms of micro-nutrients between fish and other food already exist (Kawarazuka and Béné, 2011), although not yet on a land and water footprint basis. This element of food security is not assessed here but would be an important contribution to inform regional development and decision-making in the LMB.

\section{Results}

\subsection{Water footprint}

One of the main considerations for the changes created by the LMB dam construction is the corresponding shift in the effected region's WF. Common foodstuffs contain less protein compared to calories per tonnes (Table 3 ). The resulting WF numbers are therefore generated only for protein replacement, which is assumed to be in proportion to the existing pattern as presented in Table 2. The quantity of livestock products are calculated using conversion factors for different livestock products (Table 3 ). The equivalent but additional WF under two scenarios is calculated by multiplying the quantity of livestock products (tonnes/y) by its virtual water content $\left(\mathrm{m}^{3} /\right.$ tonnes) for each country. The total additional water needed to support this protein equivalent in the LMB countries is presented in Table 5 for both the scenarios.

The water required for protein from livestock will increase water use in the entire LMB region by a minimum of $4-7 \%$ (Table 5, Scenario 1). Averages generated are skewed as data has been collected by country. If disaggregated data were used, the average would be higher. This is reflected in the assessment for Cambodia (29-64\%) and Laos (12-24\%) because their territory, as opposed to Thailand and Viet Nam, is entirely within the Basin. Under scenario 2, the water increases are on average 6$17 \%$, and again for Cambodia (42-150\%) and Laos (18-56\%) rise considerably.

Most likely, the additional WF would be comprised of both green (effective use of rainfall) and blue (irrigation water supplies) water, but each with different social, economic and environmental implications and opportunity costs based on what policy options are chosen and what support for agricultural expansion and technology is provided. If the existing pattern of livestock production is to prevail, green water use would be expected; yet this would require a larger allocation of suitable land to capture and optimise rainfall.

\subsection{Land footprints}

The different livestock used to produce the various non-fish protein listed in Table 2 have different land use requirements. Buffalo for example requires pasture land, whereas chickens can

Table 4

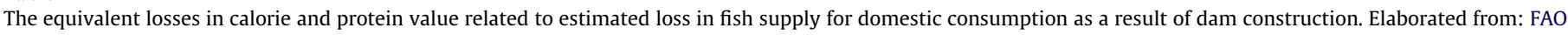
(2001) and ICEM (2010a,b). The energy and protein lost as a portion of the non-fish meat and milk products draws from Table 2.

\begin{tabular}{|c|c|c|c|c|c|c|}
\hline & & Cambodia & Laos & Thailand & Viet Nam & $\begin{array}{l}\text { Mekong } \\
\text { Basin }\end{array}$ \\
\hline $\begin{array}{l}\text { National portion of Mekong Basin fish } \\
\text { catch (\%) (ICEM, 2010a) }\end{array}$ & $\begin{array}{l}\text { Min } \\
\text { Max }\end{array}$ & $\begin{array}{l}23 \\
51\end{array}$ & $\begin{array}{l}4 \\
8\end{array}$ & $\begin{array}{l}27 \\
35\end{array}$ & $\begin{array}{l}18 \\
34\end{array}$ & \\
\hline $\begin{array}{l}\text { Scenario } 1 \text { ( } \mathrm{S} 1-11) \\
\text { Resulting losses in capture fish resources } \\
\text { in } 2030 \text { based on }-340,000 \text { tonnes per } \\
\text { year (tonnes/y) (Table } 1 \text { ) }\end{array}$ & $\begin{array}{l}\text { Min } \\
\text { Max }\end{array}$ & $\begin{array}{r}78,200 \\
173,400\end{array}$ & $\begin{array}{l}13,600 \\
27,200\end{array}$ & $\begin{array}{r}91,800 \\
119,000\end{array}$ & $\begin{array}{r}61,200 \\
115,600\end{array}$ & $\begin{array}{l}340,000 \\
340,000\end{array}$ \\
\hline Fish energy losses at $69 \mathrm{Kcal} / 100 \mathrm{~g}\left(\mathrm{Kcal} \times 10^{6} / \mathrm{yr}\right)$ & $\begin{array}{l}\text { Min } \\
\text { Max }\end{array}$ & $\begin{array}{r}53,958 \\
119,646\end{array}$ & $\begin{array}{r}9,384 \\
18,768\end{array}$ & $\begin{array}{l}63,342 \\
82,110\end{array}$ & $\begin{array}{l}42,228 \\
79,764\end{array}$ & $\begin{array}{l}234,600 \\
234,600\end{array}$ \\
\hline $\begin{array}{l}\text { Resulting energy lost as a portion of the } \\
\text { non-fish meat and milk diet development (\%) }\end{array}$ & $\begin{array}{l}\text { Min } \\
\text { Max }\end{array}$ & $\begin{array}{l}14 \\
30\end{array}$ & $\begin{array}{r}6 \\
12\end{array}$ & $\begin{array}{l}2 \\
2\end{array}$ & $\begin{array}{l}1 \\
2\end{array}$ & $\begin{array}{l}2 \\
2\end{array}$ \\
\hline Fish protein losses at $11 \mathrm{~g} / 100 \mathrm{~g}$ (tonnes/y) & $\begin{array}{l}\text { Min } \\
\text { Max }\end{array}$ & $\begin{array}{r}8602 \\
19,074\end{array}$ & $\begin{array}{l}1496 \\
2992\end{array}$ & $\begin{array}{l}10,098 \\
13,090\end{array}$ & $\begin{array}{r}6732 \\
12,716\end{array}$ & $\begin{array}{l}37,400 \\
37,400\end{array}$ \\
\hline $\begin{array}{l}\text { Resulting protein lost as a portion of the } \\
\text { non-fish meat and milk diet (\%) }\end{array}$ & $\begin{array}{l}\text { Min } \\
\text { Max }\end{array}$ & $\begin{array}{l}29 \\
63\end{array}$ & $\begin{array}{l}12 \\
24\end{array}$ & $\begin{array}{l}3 \\
4\end{array}$ & $\begin{array}{l}2 \\
4\end{array}$ & $\begin{array}{l}5 \\
5\end{array}$ \\
\hline $\begin{array}{l}\text { Scenario } 2 \text { (S2-88) } \\
\text { Resulting net loss in fish resources in } \\
2030 \text { based on } 495,000 \text { to } 792,000 \\
\text { tonnes per year (tonnes/y) (Table } 1 \text { ) }\end{array}$ & $\begin{array}{l}\text { Min } \\
\text { Max }\end{array}$ & $\begin{array}{l}113,850 \\
403,920\end{array}$ & $\begin{array}{l}19,800 \\
63,360\end{array}$ & $\begin{array}{l}133,650 \\
277,200\end{array}$ & $\begin{array}{r}89,100 \\
269,280\end{array}$ & $\begin{array}{l}495,000 \\
792,000\end{array}$ \\
\hline $\begin{array}{l}\text { Fish energy losses at } 69 \mathrm{Kcal} / 100 \mathrm{~g}- \\
\text { net }\left(\mathrm{Kcal} \times 10^{6} / \mathrm{yr}\right)\end{array}$ & $\begin{array}{l}\text { Min } \\
\text { Max }\end{array}$ & $\begin{array}{r}78,557 \\
278,705\end{array}$ & $\begin{array}{l}13,662 \\
43,718\end{array}$ & $\begin{array}{r}92,219 \\
191,268\end{array}$ & $\begin{array}{r}61,479 \\
185,803\end{array}$ & $\begin{array}{l}341,550 \\
546,480\end{array}$ \\
\hline $\begin{array}{l}\text { Resulting energy lost as a portion of } \\
\text { the non-fish meat and milk diet }(\%)\end{array}$ & $\begin{array}{l}\text { Min } \\
\text { Max }\end{array}$ & $\begin{array}{l}17 \% \\
60 \%\end{array}$ & $\begin{array}{r}7 \% \\
22 \%\end{array}$ & $\begin{array}{l}2 \% \\
4 \%\end{array}$ & $\begin{array}{l}1 \% \\
3 \%\end{array}$ & $\begin{array}{l}3 \% \\
4 \%\end{array}$ \\
\hline Fish protein losses at $11 \mathrm{~g} / 100 \mathrm{~g}$-net (tonnes/y) & $\begin{array}{l}\text { Min } \\
\text { Max }\end{array}$ & $\begin{array}{l}12,524 \\
44,431\end{array}$ & $\begin{array}{l}2178 \\
6970\end{array}$ & $\begin{array}{l}14,702 \\
30,492\end{array}$ & $\begin{array}{r}9801 \\
29,621\end{array}$ & $\begin{array}{l}54,450 \\
87,120\end{array}$ \\
\hline $\begin{array}{l}\text { Resulting protein lost as a portion of } \\
\text { the non-fish meat and milk diet (\%) }\end{array}$ & $\begin{array}{l}\text { Min } \\
\text { Max }\end{array}$ & $\begin{array}{r}36 \% \\
129 \%\end{array}$ & $\begin{array}{l}14 \% \\
43 \%\end{array}$ & $\begin{array}{l}4 \% \\
8 \%\end{array}$ & $\begin{array}{l}2 \% \\
6 \%\end{array}$ & $\begin{array}{l}6 \% \\
9 \%\end{array}$ \\
\hline
\end{tabular}


Table 5

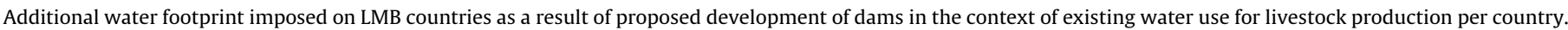

\begin{tabular}{|c|c|c|c|c|}
\hline & \multirow[t]{2}{*}{ Baseline $\mathrm{WF}^{\mathrm{a}} \mathrm{Mm}^{3} / \mathrm{y}$} & \multicolumn{3}{|c|}{ Incremental equivalent $\mathrm{WF}^{\mathrm{b}}$} \\
\hline & & $\begin{array}{l}\text { Minimum protein } \\
\text { loss }\left(\mathrm{Mm}^{3} / \mathrm{y}\right)\end{array}$ & $\begin{array}{l}\text { Maximum protein } \\
\text { loss }\left(\mathrm{Mm}^{3} / \mathrm{y}\right)\end{array}$ & $\begin{array}{l}\% \text { of the } \\
\text { current } \mathrm{WF}^{\mathrm{c}}\end{array}$ \\
\hline \multicolumn{5}{|c|}{ Scenario 1 (S1-11) } \\
\hline Cambodia & 1666 & 483 & 1071 & $29-64$ \\
\hline Laos & 793 & 96 & 192 & $12-24$ \\
\hline Thailand & 16,896 & 435 & 564 & $3-3$ \\
\hline Viet Nam & 12,514 & 249 & 470 & $2-4$ \\
\hline Total & 31,869 & 1263 & 2297 & $4-7$ \\
\hline \multicolumn{5}{|c|}{ Scenario 2 (S2-88) } \\
\hline Cambodia & 1666 & 703 & 2495 & $42-150$ \\
\hline Laos & 793 & 140 & 448 & $18-56$ \\
\hline Thailand & 16,896 & 634 & 1314 & $4-8$ \\
\hline Viet Nam & 12,514 & 362 & 1095 & $3-9$ \\
\hline Total & 31,869 & 1839 & 5351 & $6-17$ \\
\hline
\end{tabular}

a Volume of water used for total domestic production of livestock products, part of which is exported.

b Quantity and composition of additional livestock products to cover lost fish is based on existing diet pattern in these regions (see Table 2).

c \% increase in WF with respect to base line scenario.

Table 6

Increase in pasture lands in the LMB to support additional livestock production under two scenarios. FAO (2008).

\begin{tabular}{|c|c|c|c|c|}
\hline & \multirow[t]{2}{*}{ Baseline pasture land $2005^{\mathrm{a}} \mathrm{km}^{2}$} & \multicolumn{3}{|c|}{ Incremental pasture land required } \\
\hline & & $\begin{array}{l}\text { Minimum protein } \\
\text { substitution }\left(\mathrm{km}^{2}\right)\end{array}$ & $\begin{array}{l}\text { Maximum protein } \\
\text { substitution }\left(\mathrm{km}^{2}\right)\end{array}$ & $\begin{array}{l}\% \text { of the current } \\
\text { pasture land }\end{array}$ \\
\hline \multicolumn{5}{|c|}{ Scenario 1 (S1-11) } \\
\hline Cambodia & 15,000 & 3751 & 8317 & $25-55$ \\
\hline Laos & 8780 & 815 & 1630 & 9-19 \\
\hline Thailand & 8000 & 210 & 273 & 3 \\
\hline Viet Nam & 6420 & 87 & 164 & $1-3$ \\
\hline Total $^{\mathrm{b}}$ & 38,200 & 4863 & 10,384 & $13-27$ \\
\hline \multicolumn{5}{|c|}{ Scenario 2 (S2-88) } \\
\hline Cambodia & 15,000 & 5461 & 19,373 & $36-129$ \\
\hline Laos & 8780 & 1187 & 3798 & $14-43$ \\
\hline Thailand & 8000 & 306 & 635 & $4-8$ \\
\hline Viet Nam & 6420 & 127 & 383 & $2-6$ \\
\hline Total $^{\text {b }}$ & 38,200 & 7080 & 24,188 & $19-63$ \\
\hline
\end{tabular}

a Based on FAO, 2008 data.

b In summing the minimum and maximum figures to identify boundaries on the range of outcomes these totals inflate the minimum and maximum areas of land converted to agriculture.

utilise a range of landscapes. The expansion in pasture lands needed to sustain ruminant livestock production (e.g. buffalo, cattle or goat) in proportion to the higher levels needed to replace lost fish catch is modelled. This is a conservative calculation in assuming that the required proportional increase in 'scavenging' poultry and pig livestock would also be supported by the increase in pasture, which may not be true. The pasture land required to substitute the existing calorie and protein supply from the fish catch that would be lost with non-fish products in each LMB nation is calculated in Table 6 by extrapolating FAO data for the current area of pasture for livestock to increase production in the proportion estimated for each country in Table 2 . We assessed the same two scenarios for land use for the four LMB nations.

For Cambodia and Laos, the conversion numbers at a minimum level under both scenarios are high, equalling a $29 \%$ and $42 \%$ increase in pasture lands respectively. Under scenario 2 , the necessary increase in pasture land is significant for both Cambodia (36\% and 129\%) and Laos (14\% and 43\%). The high proportion of the population below the poverty line in Laos (31\%) and Cambodia (35\%) (ADB, 2008; FAO, 2005) suggests that the socio-economic impacts could be greatest in those countries - as these populations may be less able to afford more expensive protein substitutes.

\section{Discussion}

Our research shows that shifting the food security of 12 million households from one based on aquatic protein to land-based production will require much greater attention to the corresponding increase in water consumption and land use conversion.

An increase in WF for the LMB countries may be a minimum increase of $4-7 \%$ under scenario 1 , but would be considerably higher for two specific countries: Cambodia (29-64\%) and Laos $(12-24 \%)$. Under scenario 2, the water increases are on average 6$17 \%$, and rise considerably within Cambodia (42-150\%) and Laos (18-56\%). Cambodia and Laos are more vulnerable to change as a larger portion of their countries are dependent on fish protein; thus more resources are required to replace protein in these countries. Yet from the scenario 2 estimations, even if water resources were fully utilised, there would be a sizeable shortfall concerning domestically produced protein and calories (Table 5). Considering that most LMB states aspire to obtain benefits by exporting commodities like rice to meet increasing global demand, obstacles to achieve this goal arise when more water is consumed in protein production to meet domestic demand (CAoWMiA, 2007).

South-East Asia as a whole is not considered water scarce, yet the estimations of increased water consumption would entail huge opportunity costs. Substantial volumes of water in the natural 
environment are needed to sustain important ecosystem services in the Mekong Basin, such as capture fisheries, low-input flood recession agriculture, and maintenance of the delta (Barlow et al., 2008; Molle et al., 2009; Osborne, 2009). There are water shortages in certain parts of the region that could be exacerbated if resources are further constrained, as illustrated by the proposal for an interbasin transfer "water grid" from the Mekong River to supply water to Thailand (Lebel et al., 2005; Molle and Floch, 2007). To what extent the water gap in these countries could or would be met through rainfed agriculture and pasture systems or irrigation is uncertain.

Laos and Cambodia are seeking to increase the area of irrigated crop production by $31,000 \mathrm{~km}^{2}$ (ICEM, 2010a), yet this potential is tempered by the fact that high quality agricultural lands in the region are already under heavy use, with low or negative rates of land use conversion to agriculture. The annual growth rate in the area of agricultural land between 1980 and 1990 in each LMB nation ranged from a $-0.6 \%$ fall to a $2.7 \%$ increase (FAO, 2005). Replacing lost protein would require challenging reconfigurations of resources to accommodate the current rate of expansion. Under both scenarios, there will be a loss of $1350 \mathrm{~km}^{2}$ of land proposed for inundation that would impact the riverbank gardens of 450,000 households (ICEM, 2010a). On top of this land loss, the additional pasture land required to replace protein with livestock is estimated as at least 4863 and up to $10,384 \mathrm{~km}^{2}(13-27 \%$ increase) on average under scenario 1 , or $7080-24,188 \mathrm{~km}^{2}$ (19-63\% increase) for scenario 2. Cambodia (36\% and 129\%) and Laos (14\% and 43\%) both show considerably higher than average land needs under scenario 2.

The situation is complicated by the fact that all LMB nations import a large share of their livestock derived protein supplies, with Viet Nam and Thailand as exporters of livestock products (Table 2). The LMB nations import livestock feed, which in the case of Viet Nam and Thailand, enables their high levels of livestock production from a modest area of pasture. Further, Thailand imports large volumes of maize for livestock from Cambodia and Laos (FAO, 2008). If a 6-9\% increase in livestock production is required in the LMB nations simply to replace lost fish catch from all planned dams by 2030 (Table 4, scenario 2) then an increase in imports of livestock feeds would also be expected, increasing the global land and water footprint of their production. The higher prices of imported products would increase pressure on LMB producers to raise income to pay for foreign inputs (e.g. livestock feed), and these higher prices on products would further disadvantage the poor.

Increasing revenues from hydropower have not been shown to alleviate poverty (ICEM, 2010b). Main stem dam construction on the Mekong is likely to disproportionately impact many of the poorest people in the Basin. These social impacts on riparian communities are expected to be severe and include disruption to ways of life, cultures, sense of community, natural environment, food security, physical safety, control over resources and health and well-being (ICEM, 2010b). Poor people rely more on fisheries as a common property resource, due to lack of land ownership, debt, health issues, poor education and marginalisation from political decision making (Béné and Friend, 2011). Fishing also involves and enhances the status of women (Kawarazuka and Béné, 2010, Béné and Friend, 2011 ) in terms of their traditional access to and participation in the industry. Many of the current capture fisheries are produced by local people for their own consumption. This serves as a diversified livelihood strategy (Béné and Friend, 2011) that helps ensure food security, generate income, and acts as insurance against crop failure, providing an important safety net (Baran and Myschowoda, 2009; Kawarazuka and Béné, 2010; Arthur and Friend, 2011). Furthermore, the main stem dams would directly affect 190 villages and 107,000 people (ICEM, 2010b).
The quality of nutrition linked to replacement proteins is another consideration. Sixty million people in the Basin consume on average $27 \mathrm{~kg}$ of fish per year, representing a major source of amino acids, calcium, iron, protein, vitamin A and protein (Baran and Myschowoda, 2009; Kawarazuka and Béné, 2010, 2011). Diet and health would undergo a forced diversion from a fundamental source of nutrition, which is another aspect of disruptions. There is substantial poverty in Laos, Cambodia and Viet Nam, and in the LMB nations there are 2.9 million people who are regarded as vulnerable to even a $10 \%$ increase in food prices (ADB, 2008).

The unanticipated impacts of the proposed dams on protein supply, and water and land resources raise the question of whether there are better ways of optimising energy and food supplies while sustaining food security and the environment. In light of the externalities identified here, alternative energy supply options should be assessed for the lower Mekong region (TNFC and PI, 2009; ICEM, 2010a). Locating new dams at less environmentally and socially damaging locations off the main stem of the Mekong using processes such as those assessed by King et al. (2007), should also be considered.

\section{Conclusion}

Hydropower development is often justified by the projections of social and economic advantages, using assessment processes that are often narrowly focussed only on the environmental and social impacts of the areas directly impacted by dam construction and inundation (WCD, 2000). Indeed the current assessment processes underway for the proposed dams on the main stem of the LMB appear to mirror this approach. This assessment expands the issue of impacts to include a first assessment of protein replacement scenarios due to projected losses to the capture fishery of the Mekong Basin, which is the primary source of protein for the 60 million residents of the LMB. The essence of this research has been to identify and anticipate where burdens of shifts within food security will be borne. This type of analysis could be employed in almost any area where inland fisheries make up a portion of food security.

Highlighting the nature of impacts from constructing hydropower dams through displacement of ecosystem services particularly those which are not normally assessed - is crucial to deciding whether to proceed with such infrastructure - and if so, where. Although Laos aspires to be the "battery of Asia" through hydropower, the water and land assessments suggest that such development would incur severe impacts on fisheries with extended implications, not to mention great social costs.

The data used in our assessment is the best available and these findings are first approximations on land and water requirements. The methods adopted here to estimate the impact on protein supplies due to dam construction are conservative in the use of SEA assessments of loss in fish production, and scaling up supply of other proteins in proportion to their existing consumption. FAO and MRC data used here does not yet account for future population increases and resulting demand for protein. Similarly, other possible protein scenarios could be modelled and would add considerably to a wider understanding of the impacts and options available. Fuller estimations are required to establish more detailed accounting of food costs, land and water use and access, livelihoods, equity and poverty. Studies for individual nations will determine a wider range of impacts and explore the institutional challenges that lay ahead. This way the benefits of dams can be better compared to the negative trade-offs involved.

\section{Acknowledgements}

Initial research for this article by J. Pittock was funded by WWF International. Marc Goichot, WWF Greater Mekong Programme, 
provided advice in the preparation of this article. Mr Mishka Talent, ANU, assisted this work with collation of FAO data. The helpful comments of Phil Fearnside [reviewers and editors] were greatly appreciated.

\section{References}

ADB, 2001. Reality check of the WCD guidelines. A case study for the Nam Theun 2 Hydro-Electric Project in Lao PDR, ADB workshop to discuss the World Commission on Dams report Dams and Development. Asian Development Bank, Manila, Philippines.

ADB, 2008. Key Indicators for 2008 for Asian and the Pacific, 39th edition. Asian Development Bank, Manila, Philippines.

Allan, J.A., 1998. Virtual water: a strategic resource global solutions to regional deficits. Ground Water 36, 545-546.

Allan, J.A., 2001. The Middle East Water Question: Hydropolitics and the Global Economy. I.B. Tauris, London.

Amornsakchai, S., Annez, P., Vongvisessomjai, S.(TDRI), Choowaew, S.T.D.R.I., Kunurat, P., Nippanon, J., Schouten, R., Sripapatrprasite, P., Vaddhanaphuti, C., Vidthayanon, C., Wirojanagud, W., Watana, E., 2000. Pak Mun Dam, Mekong River Basin, Thailand. A WCD Case Study prepared as an input to the World Commission on Dams. World Commission on Dams, Cape Town.

Arthur, R.I., Friend, R.M., 2011. Inland capture fisheries in the Mekong and their place and potential within food-led regional development. Global Environmental Change 21, 219-226.

Baird, I.G., Mean, M., 2005. Sesan River fisheries monitoring in Ratanakiri province, northeast Cambodia: Before and after the construction of the Yali Falls dam in the Central Highlands of Viet Nam. 3S Rivers Protection Network and Global Association for People and the Environment, Ban Lung, Cambodia.

Baran, E., Myschowoda, C., 2009. Dams and fisheries in the Mekong Basin. Aquatic Ecosystem Health \& Management 12, 227-234.

Barlow, C., Baran, E., Halls, A.S., Kshatriya, M., 2008. How much of the Mekong fish catch is at risk from mainstream dam development? Catch and Culture 14, 16-21.

BBC, 2011. Laos' Mekong Xayaburi dam plan delayed again. News Asia, December 8 , 2011. Found at http://www.bbc.co.uk/news/world-asia-16085584.

Béné, C., Friend, R., 2011. Poverty in small-scale inland fisheries: old issues, new analysis. Progress in Development Studies 11 (2), 119-144.

Bonn, 2011. Bonn, 2011 Nexus Conference. Policy recommendations at http:// www.water-energy-food.org/en/conference/policy_recommendations.html.

Campbell, I.C., 2009. The Mekong. Biophysical Environment of an International River Basin. Elsevier, Maryland Heights, USA.

CAoWMiA, 2007. Water for Food, Water for life. A Comprehensive Assessment of Water Management in Agriculture. Earthscan \& International Water Management Institute, London \& Colombo.

Chapagain, A.K., Hoekstra, A.Y., 2004. Water footprints of nations, Value of Water Research Report Series No. 16. UNESCO-IHE, Delft, the Netherlands.

Chapagain, A.K., Hoekstra, A.Y., 2008. The Global Component of Freshwater Demand and Supply: An Assessment of Virtual Water Flows between Nations as a result of Trade in Agricultural and Industrial Products, vol. 33. Water International, pp. 19-32.

de Fraiture, C., Cai, X., Amarasinghe, U., Rosegrant, M., Molden, D., 2004. Does International Cereal Trade Save Water? The Impact of Virtual Water Trade on Global Water Use. Comprehensive Assessment Research Report 4. Comprehensive Assessment Secretariat, Colombo, Sri Lanka.

Dugan, P., 2008. Mainstream dams as barriers to fish migration: international learning and implications for the Mekong. Catch and Culture 14, 9-15.

Eley, T.J., Watkins, T.H., 1991. The uncertain fate of the Pacific salmon: in a sea of trouble. Wilderness 55, 18.

FAO, 2001. Food Balance Sheets: A handbook. Food and Agriculture Organization of the United Nations, Rome, Italy.

FAO, 2005. Livestock Sector Briefs. Food and Agriculture Organisation of the United Nations.

FAO, 2008. FAO Statistical Yearbook 2007-2008. Food and Agriculture Organisation of the United Nations.
Friend, R., 2009. Fishing for influence: fisheries science and evidence in water resources development in the Mekong Basin. Water Alternative 2 (2), 167-182

Hoekstra, A.Y., Chapagain, A.K., Aldaya, M.M., Mekonnen, M.M., 2011. The Water Footprint Assessment Manual: Setting the Global Standard. Earthscan.

Hortle, K.G., 2007. Consumption and the Yield of Fish and Other Aquatic Animals from the Lower Mekong Basin. Mekong River Commission, Vientiane, Lao PDR

ICEM, 2009. MRC SEA of hydropower on the Mekong mainstream. Inception report vol. II. Mainstream project profile summaries. Mekong River Commission, Vientiane.

ICEM, 2010a. MRC SEA for Hydropower on the Mekong mainstream. Fisheries Baseline Assessment Working Paper. International Center for Environmental Management, Hanoi.

ICEM, 2010b. MRC Strategic Environmental Assessment (SEA) of hydropower on the Mekong mainstream: Final report. International Center for Environmental Management, Hanoi.

IHA, 2006. Sustainability Assessment Protocol. International Hydropower Association, Sutton.

Kawarazuka, N., Béné, C., 2010. Linking small-scale fisheries and aquaculture to household nutritional security: an overview. Food Security 2, 343-357.

Kawarazuka, N., Béné C., 2011. The potential role of small fish in improving micronutrient deficiencies in developing countries: building the evidence Public Health Nutrition. Available on line doi:10.1017/S136 8980011000814.

King, P., Bird, J., Haas, L., 2007. The Current Status of Environmental Criteria for Hydropower Development in the Mekong Region. A Literature Compilation. Asian Development Bank, Mekong River Commission, WWF, Vientiane.

Lebel, L., Garden, P., Imamura, M., 2005. The politics of scale, position, and place in the governance of water resources in the Mekong region. Ecology and Society 10,18 (online).

Mekonnen, M.M., Hoekstra, A.Y., 2011. National water footprint accounts: the green, blue and grey water footprint of production and consumption, Value of Water Research Report Series No. 50. UNESCO-IHE, Delft, the Netherlands.

Molle, F., Floch, P., 2007. Water, Poverty and the Governance of Megaprojects: The Thai "Water Grid". Institut du Recherche pour le Developpement, Mekong Program on Water Environment and Resilience. International Water Management Institute, Montpellier.

Molle, F., Foran, T., Kakonen, M., 2009. Contested Waterscapes in the Mekong Region: Hydropower, Livelihoods and Governance. Earthscan, London.

Moore, D., Dore, J., Gyawali, D., 2010. The World Commission on Dams + 10: revisiting the large dam controversy. Water Alternatives 3, 3-13.

MRC, 2005. Overview of present knowledge of the Lower Mekong River ecosystem and its users. MRCS Internal Working Paper Draft: 10 November 2005, Mekong River Commission Water Utilization Program/Environment Program Integrated Basin Flow Management. Mekong River Commission, Vientiane, Lao PDR.

Oki, T., Kanae, S., 2004. Virtual water trade and world water resources. Water Science \& Technology 49, 203-209.

Osborne, M., 2009. The Mekong: River under Threat. Lowy Institute for International Policy, Sydney, PDR.

Richter, B.D., Postel, S., Revenga, C., Scudder, T., Lehner, B., Churchill, A., Chow, M., 2010. Lost in development's shadow: the downstream human consequences of dams. Water Alternatives 3 (2), 14-42.

Söderbaum, P., 2009. Democracy and sustainable development-what is the alternative to cost-benefit analysis? Integrated Environmental Assessment and Management 2 (2), 182-190.

Smith, L., Nguyen Khoa, S., Lorenzen, K., 2005. Livelihood functions of inland fisheries: policy implications in developing countries. Water Policy 7, 359-383.

The Theun-Hinboun Power Company Limited, 2000. The Theun-Hinboun Power Company's mtigation and compensation program. The Theun-Hinboun Power Company Limited, Vientiane, Lao TNFC \& PI (2009) Powering 21st century Cambodia with decentralized generation.In: The NGO Forum on Cambodia and Probe International, Phnom Penh and Toronto.

WCD, 2000. Dams and development: a new framework for decision-making. The Report of the World Commission on Dams. Earthscan, London.

WEF, 2011. Water Security: The Water-Food-Energy-Climate Nexus. WEF Water Initiative. Island Press, Washington DC, USA.

WWF, 2005. To Dam or Not to Dam? Five Years on from the World Commission on Dams. WWF International, Gland. 